INTERNATIONAL JOURNAL OF MULTIDisciplinARY RESEARCH AND ANALYSis

ISSN(print): 2643-9840, ISSN(online): 2643-9875

Volume 04 Issue 10 October 2021

DOI: 10.47191/ijmra/v4-i10-02, Impact Factor: 6.072

Page No.- $1353-1360$

\title{
Business Perception as a Strategy for Sustaining Entrepreneurship in the Face of Insurgency in Niger State, Nigeria
}

\author{
Anoke, Amechi Fabian ${ }^{1}$, Osita, Fabian Chinedu' ${ }^{2}$ Eze Solomon Uchechukwu ${ }^{3}$, Muogbo Uju Sussan ${ }^{4}$ \\ 1,2,3 Department of Business Administration, Nnamdi Azikiwe University, Awka; Anambra State, Nigeria. \\ ${ }^{4}$ Department of Entrepreneurship Studies, Chukwuemeka Odumegwu Ojukwu University, Igbariam, Anambra State Nigeria
}

ABSTRACT: The Nigerian business environment is unfriendly considering the insecurity situation that characterized the atmosphere which resulted in many businesses being halted while others are forced to outright closure, especially in Niger state. As a result, government and policymakers in the state invest, support, and encourage entrepreneurs to sustain them. However, despite these huge investments and strategies adopted to promote and sustain entrepreneurship activities in the state by policymakers, entrepreneurs continued to perform below expectation. The study, therefore, examined perception as a strategy for sustainable entrepreneurship in the face of insurgency in Niger State. 315 respondents were used as the population as well as the sample size of the study. Simple linear regression was used to analyze the stated hypothesis. The study found a strong and positive relationship between business perception and entrepreneurship sustainability in Niger State. The study concludes that business perception is a strategy for sustainable entrepreneurship in Niger State and recommended that there should be proper orientation and encouragement to Niger State entrepreneurs to maintain or even improve on their current entrepreneurial mindset, perceiving entrepreneurial opportunities amidst insecurity challenges.

KEYWORDS: Business-perception, Entrepreneurship, Insurgency, Strategy, and Sustainability

\section{INTRODUCTION}

In the last few years, the general attention of the Nigerian government and policymakers has shifted greatly to entrepreneurship development, and sustainability due to the pivotal role the sector plays in stabilizing the fragile economy. This paradigm shift is due to the economic contribution that entrepreneurs are offering to the growth, development and sustainability of the economy of any country that sees this important sector as a bridging gap. The focus on this untapped source of growth and sustainability seems to be crucial today for development practitioners. Entrepreneurs are gradually taking a center stage, reviving broken economies and sustaining healthy ones (Akpofi, 2019).

Adaba(2020) noted that entrepreneurs contribute mostly to the economy through wealth creation, employment generation, entrepreneurial ecosystem, and profits redistribution. It is commonly believed that the benefits of entrepreneurship are in its creativity, innovativeness, and its employment generation abilities at a low price. The labour strength and employment capacity of the entrepreneurial sector especially in developing countries like Nigeria are far much higher than that of large ventures. In most African countries like South Africa, Ghana, Kenya, Senegal, etc, entrepreneurship and entrepreneurial activities have provided more than sixty-five per cent (65\%) of total labour engagement and contributed more than forty-five percent (45\%) of GDP and increased their per capita income in 2019 after a sharp drop in the oil prices at the international market (Gbande, 2018). It is equally on record that many countries of the world depend on the private sector that is most entrepreneurs to think outside the box, come up with workable options to rebuild the economy after the Covid-19 pandemic that brought the world economy to a halt (Ajah, 2020).

Nigeria, just like most developing countries has keyed in and become more interested in the development and sustainability of entrepreneurship activities now ever than before because of its potential multiplier effects in the area of economic stabilization, job creation, developmental ability, promotion of indigenization, and equitable distribution of income(Joel,2019).

Amidst these applauds; entrepreneurs in Nigeria especially in Niger state are faced with challenges among which are insurgency, kidnapping, herders-farmers clashes, etc, which have affected the growth and sustainability of entrepreneurship activities in that area in no small measure. Tende(2019) opined that insurgencies develop in a small group and become sustained not because 


\section{Business Perception as a Strategy for Sustaining Entrepreneurship in the Face of Insurgency in Niger State, Nigeria.}

insurgents defeat government machinery in a conventional war but because the instrument of government is considering the fundamental human right and rules of engagement. The insurgents equally manage to remain in existence for this period because they manage to win support - finance, sponsorship, relive materials, hearts and minds among the populace as they hit and retreat to hide within the society, recruit more members, and attack like guerrilla warfare.

Government having observed the pivotal roles entrepreneurs and entrepreneurial activities play in stabilizing the economy especially in this Covid-19 pandemic Era and the unpatriotic activities of the insurgents in the State in making sure that this dream is unrealized; policymakers in Niger state keep investing and supporting entrepreneurial culture through business initiatives that build business confidence, positive perception, entrepreneurial alertness, positive attitudinal change towards entrepreneurship, support innovativeness, provision of new and modern business technological equipment, encouraging business networking as well as inter-business linkages and encouragement of business research. However, despite these initiatives, supports, huge investments, and strategies adopted to promote and sustain entrepreneurship activities in the state by policymakers, entrepreneurs continued to perform below expectation and the need to investigate its relevance to the entrepreneurship sustainability in Niger state becomes research in the right direction.

The main objective of this study is to investigate the effect of business perception on entrepreneurship sustaining in the face of insurgency in Niger state, Nigeria.

In line with the objective of the study, the following hypothesis was developed and tested:

H01: Business perception has no significant effect on entrepreneurs' sustainability in Niger State.

\section{REVIEW OF RELATED LITERATURE}

\section{Concept of Entrepreneurship}

Entrepreneurship and entrepreneurial activities in any typical developing country like Nigeria attract 45 percent of the GDP and employs more than 75 percent of their total workforce and this is why no meaningful and focused government can toy around with this active segment of the populace (Mbam, 2021).

Tende (2018) noted that for result-oriented managers to be proactive, productive, successful, and sustain their business ventures, they are required to develop new methods, techniques, strategies, and approaches to navigate out of the ever-challenging business environment. Such a strategy for sustaining the economic tempo in any nation becomes a source of concern to the players. The concept of entrepreneurship is as old as a man because it has existed for ages and is considered to be the brain behind the economic revitalization

Anoke (2019) noted that the public sector alone cannot single-handedly develop, drive and sustain any economy to an enviable height without the active involvement and participation of the private sector (Entrepreneurs and entrepreneurship). Onu (2018) posits that the success and economic failure of any society depend largely on the level of attention given to her entrepreneurship and entrepreneurial related activities. This owes to the fact that education leads to creativity and awareness while entrepreneurial alertness also equips and reshapes entrepreneurs' perceptions and innovative tendencies for better entrepreneurship sustainability.

\section{Insurgency and Entrepreneurship Sustainability}

In Nigeria today, from the North East of Yobe, Borno and Adamawa; North West of Kastina, Zamfara and Kaduna; North Central of Benue, Plateau, and Niger; South West of Ondo, Ekiti and Oyo; South East of Abia, Imo, and Ebonyi through the South-South of Rivers, Edo, and Bayelsa, insurgents have been destroying the economic activities, killing entrepreneurs and burning down their properties in a bid to prove a negative point and these left entrepreneurs and companies in these states with no options but to fold up and move to more comfort zone including outside the country with the mind-set that only the living can do business (Ezekiel,2019). The aforementioned states are the most affected while the remaining states in the respective geopolitical zones in Nigeria including the Federal Capital Territory have had their share in the insurgent activities at one time or the other which affects economic activities and entrepreneurs in no small means (Mbeh, 2019). Eze(2019) noted that the frequent battle between insurgents and the Nigerian enforcement agencies brings about killing and destruction of property in many states of the country especially Niger state and entrepreneurs are the worst hit. This no doubt is the reason why many entrepreneurs, especially those from the South-eastern part of Nigeria who is predominantly entrepreneurs and businessmen flew from these states for their lives with their businesses either relocated or in worst cases abandoned (Adebayo, 2020).

In Niger State, from Suleja ( A bordering town to the Federal Capital Territory) to Minna(the state capital); from Bida(the commercial nerve center of the state) to Lapai(the food basket of the state), the story of insurgency remains the same as entrepreneurs' lives are threatened, their shops closed down (if not completely destroyed) and business hours drastically reduced to more than half, the roads, streets, markets are no longer safe for business operation, goods hardly come in or go out of the 


\section{Business Perception as a Strategy for Sustaining Entrepreneurship in the Face of Insurgency in Niger State, Nigeria.}

state due to fear of the unknown(Yahaya, 2019). The economic activities in the state were brought to a standstill in February, 2021 when the constant attack targeted at entrepreneurs and government facilities metamorphosed into kidnapping school children and the impact of that action on the business community was better imagined than experienced (Lukman, 2020).

In general, the insurgency has increased the cost of doing business by entrepreneurs, and the burden is always shifted to the final consumers since entrepreneurs are profit-oriented. The government is equally not spared in this 'ugly game' as the resources that would have been devoted to increasing creativity, innovation, supporting education, health, and other entrepreneurial activities in the state are being diverted to fighting crime, criminalities, and prevention in the state Ndako(2020). However, Abbah(2020) noted that in the amid these challenges faced by entrepreneurs orchestrated by stoned-hearted insurgents, entrepreneurs still perceive entrepreneurial activities positively.

\section{Entrepreneurship Sustainability}

Sustainability refers to the ability to maintain a certain standard, level, or rate. It can also be seen as the ability of providing necessitates of the people today without sub changing the ability of the unborn to have theirs. Barde(2018) noted that entrepreneurship sustainability is relatively a new idea that connects development with business actions. Researchers have attempted to define sustainable entrepreneurship according to the side or angle they viewed the subject matter. Some pollsters saw it as sustainability-straighten entrepreneurship (Abdul, 2017); sustainable-minded entrepreneurship (Fatai, Rowland \& Omisade, 2016). Other studies have also linked it to balancing environmental factors with entrepreneurship (Ohida, 2018; Anda, 2017). Therefore, to sustain entrepreneurship, entrepreneurs must take the necessary business risk, be innovative and support the entrepreneurial ecosystem by ensuring that businesses are done sustainably.

\section{Self- Perception and Business Sustainability}

An entrepreneur can perceive his business from three different angles. That is, how the entrepreneur perceives the business himself, how others perceive the entrepreneur about the business, and how the entrepreneur perceives his business environment. These key factors play a vital role in the success or otherwise in the entrepreneur's business life cycle (Osita, 2020).

Utara (2019) noted that how entrepreneurs perceive business is fundamental to the sustainability of such business. Entrepreneurs who display entrepreneurial characteristics are more likely to experience greater success in business as they run their ventures more profitably than those who are entrepreneurially naïve. In addition, entrepreneurs who found their businesses more profitable are also more likely to sustain such businesses over a longer period as entrepreneurs are profit-oriented. Normally, it is assumed that as long as an entrepreneur continued to enjoy his business profitably through customer satisfaction and positive returns, the more likely is that such business will be sustained and continue to succeed. Abdullsalami(2020) posits that at the centre of insurgency in Niger state, entrepreneurs still believe that there is light at the end of the tunnel. There are entrepreneurial opportunities amidst insecurity as some of them are into pharmaceuticals, supply of non-sensitive military equipment to combat crimes and criminalities, foods, water, transportation that are essential for the survival of businesses and individuals in times of insecurity.

\section{Entrepreneurs' Perception of the Business Environment and Business Sustainability}

Chinedu (2020) noted that business environment, and culture is pivotal for business development, growth and sustainability. The immediate business environment in which one operates builds or destroys such business if not well factored in because such factors are uncontrollable. It is noteworthy that cultural and social norms have quantifiable weight on the ways that businesses are established, managed, and even promoted in a given area. Security-conscious entrepreneurs tend to recognize this fact and devise a means of navigating through the unfriendly business environment like in Niger state for optimal performance. This they do by catering to the needs and wants of their target market(s)/customers by providing the required goods and services in a way that will be appealing to them. This effort can only be fruitful and productive if the entrepreneur perceives the business environment and other forces surrounding business activities in a good light (Ayodeji, 2018). Additionally, the success or failure of entrepreneurship in a particular environment hovers around the norms, values, and culture of such people. Wrong perception and assumptions regarding the market needs, culture, and custom will create a business gap between services offered and services required (Idris, 2019). In general terms, Jato(2019) noted that the inevitability of accurate need fulfillment in an unsecured business environment like in Niger State today cannot be overstated in the perilous business environment that entrepreneurship exists. The solution to this immediate problem and the sustainability of entrepreneurial businesses, therefore, lies in entrepreneurship education, conscientization of the people, and development of acquaintance with the business environment especially in Niger state (Adaba, 2020).

\section{Empirical Studies}

Josiah (2017) examined the influence of perceptions on entrepreneurial success. The study focused on three types of perceptions 


\section{Business Perception as a Strategy for Sustaining Entrepreneurship in the Face of Insurgency in Niger State, Nigeria.}

and how they influence business success. These include how entrepreneurs perceive themselves, the perception they have of their business environments and the perceptions others have of them. The study found that entrepreneur's self- perception for business and how entrepreneurs perceive their business environment are key determinant factors for entrepreneurs' business success. The study recommended among others that there should be entrepreneurship orientation among the youths to redirect their entrepreneurial mindset early enough.

The study of Josiah (2017) can only be considered as novel writing as all the ingredients of research writing are conspicuously missing. Such vital elements like location, population, sample size, and sample size determination formula, method of data collation as well as the method of data analysis are all missing in the study.

Fatai and Farida(2016) carried out research to determine the effect of knowledge sharing(KS) and business perception(BP) on the performance of SMEs in Indonesia. Samples were employed from 80 SMEs in the study area. Randomly Path Analysis was also employed to test the formulated hypothesis. The result of the study revealed that KS has a positive and significant relationship with SMEs performance while BP recorded an inverse relationship with SMEs' performance in Indonesia. The study recommended that small business operators should willingly share their acquired or gained knowledge for SMEs optimal performance.

The study of Fatai and Farida (2016) lagged in the following ways. The population from where the sample size of 80 SMEs was drawn was not stated, a sample size of 80 respondents from a country like Indonesia with a burning national issue like SMEs performance is grossly inadequate to be relied upon and draw a conclusion and make recommendation therein. In addition, a random selection of respondents used in the study is unacceptable and does not have scientific backing since there is a likelihood that some respondents that would have ordinarily been included in the sample will be shut out. They would have used a sample size determination formula like Yamane's (1967) or even Roasoft. Finally, the method of data collection used in the study was not stated.

Fatai, Rowland, and Omisade(2016) examined critical issues for sustainable entrepreneurship. The study employed a secondary source in collecting data for the study. Information regarding attitude, firm size, ownership, innovativeness, business perception among others was considered as key drivers of entrepreneurship sustainability. The study found that all the drivers in the study were essential for sustainable entrepreneurship and recommended that government and its institutions should key into the drivers and provide a window that will foster entrepreneurship sustainability. The study of Fatai, Rowland, and Omisade(2016) besides omitting the population and the sample size of the study, did not equally state the location of the study which is vital in any research work.

\section{Theoretical Framework}

The theory that this study is rooted in is the entrepreneurship theory. As value creation, entrepreneurial theory explains the experience of entrepreneurs in its fullest form, starting from entrepreneurial intention, idea generation to opportunity recognition and development of entrepreneurial competencies as well as resistance to external and environmental factors surrounding the business and the eventual reward, it is therefore imperative that entrepreneurs should focus on the end and not the means even as they operate in an unfriendly business environment (Mishra \& Zachary 2014).

\section{METHODOLOGY ADOPT}

A survey research design was adopted in this study because the data used were collected through a structured questionnaire administered to the sampled respondents who are entrepreneurs in the study area. The population of the study was all entrepreneurs who registered with the Niger State Internal Revenue Board (NSIRB) and have paid all their capital gain tax, valueadded tax, personal tax as well as withholding tax as of $31^{\text {st }}$ December 2020 to the state coffers. 315 entrepreneurs met these conditions and were used as both the population and sample size due to the small nature of the population.

The questionnaire was proposed on a five (5) point likert scale to collect information from the sampled respondents. The coding was ranked 5,4,3,2,1 representing, Strongly Agreed(SA), Agreed(A), Undecided(UD), Disagreed(DA) and Strongly Disagreed(SD) respectively. 305 respondents filled and returned their questionnaire and ware used for the analysis while 10 respondents could not return theirs.

Niger State was chosen in this study due to the persistent attack on entrepreneurs by the insurgents disturbing the use to be peaceful and power state of Nigeria.

To maintain the validity of the instrument, the first draft of the questionnaire went through content and face confirmation. The instrument was given to experts in the Entrepreneurship Development Centre, IBB University, Lapai, Niger State. The experts in the centre were employed to examine the items in the instrument and air their views on the suitability and clarity of the statement. Their comments and inputs were used to amend and produce the final copy. 
Business Perception as a Strategy for Sustaining Entrepreneurship in the Face of Insurgency in Niger State, Nigeria.

To ensure that the questionnaire was reliable, a reliability test was conducted using Cronbach's Alpha and was found to be statistically standard. The reliability of the questionnaire was found not to be less than the Alpha value of 0.7 as approved by Nunnally (1978)

1. Summary of the Reliability Measurement (Cronbach's Alpha)

\begin{tabular}{ll}
\hline Questionnaire Variables & Cronbach's Alpha \\
\hline Business Perception & 0.795 \\
Entrepreneurs Sustainability & 0.781 \\
\hline Source: SPSS-25, 2021 &
\end{tabular}

Table 1 reveals that the reliability of the variables has Alpha value above 0.70, which implies that they are reliable.

Simple regression and simple percentages are statistical tools used to analyze the collected data. The simple regression was used to determine if there is an effect relationship between the dependent and independent variables in the study.

This is expressed in this study as follows:

$\mathrm{Y}=\alpha+\beta_{1} x$

1, $\mathrm{Y}=$ dependent variable, $\alpha$ =intercept, $\beta_{1}$ =coefficient, $\mathrm{X}$ is the independent variable.

$\mathrm{ES}=\alpha+\beta_{1} \mathrm{BP}+\mu$ 2. Where: $\mathrm{ES}=$ Entrepreneurship Sustainability. $\beta$ = coefficient, $\alpha$ =intercept, $\mu$ =error term.

\section{RESULTS AND DISCUSSION}

Table 2: Descriptive Statistics

\begin{tabular}{|c|c|c|c|c|c|}
\hline $\mathrm{S} / \mathrm{N}$ & Variables & $\mathrm{N}$ & $\mathrm{FX}$ & $\operatorname{Mean}(\mathrm{x})$ & Remark \\
\hline & Strategies for Business Sustainability & & & & \\
\hline 1 & Perception is a strategy for entrepreneurship sustainability & 305 & 1189 & 4.01 & SA \\
\hline 2 & $\begin{array}{l}\text { Innovativeness and positive business risk by entrepreneurs help to } \\
\text { sustain business }\end{array}$ & 305 & 1115 & 3.66 & A \\
\hline 3 & Entrepreneurs perceive business negatively due to insurgency & 305 & 354 & 1.16 & SD \\
\hline 4 & Entrepreneurship education helps in business sustainability & 305 & 1334 & 4.37 & SA \\
\hline 5 & Environmental knowledge does not affect business sustainability & 305 & 610 & 2.00 & DA \\
\hline \multirow[t]{2}{*}{6} & Sustained business straightens entrepreneurs in Niger State & 305 & 1095 & 3.51 & A \\
\hline & Effect of Insurgency on Business Sustainability & & & & \\
\hline 7 & Amidst insurgency, entrepreneurship activities can be sustained & 305 & 1193 & 3.91 & A \\
\hline 8 & The insurgency has halted many businesses and others quit Niger State & 305 & 1389 & 4.55 & SA \\
\hline 9 & $\begin{array}{l}\text { Entrepreneurship sustainability doesn't depend on the level of peace } \\
\text { securitv in that area }\end{array}$ & 305 & 425 & 1.39 & SD \\
\hline 10 & Insecurity limits the sources of funds available to entrepreneurs & 303 & 1254 & 4.11 & SA \\
\hline
\end{tabular}

Source: Field Survey, 2021

N/B. $S A=$ strongly agreed, $A=$ agreed, UD= Undecided, $D A=$ Disagreed, and SD= strongly Disagreed. This study adopted Amal (2016), five-point likert scale mean grouping as 1-1.99= strongly disagree, 2.00= disagree, 2.01-3.00 Undecided, 3.01-4.00= Agreed and 4.01-5.00 = strongly agreed.

From Table2, it was revealed that respondents on average, strongly agreed that perception is a strategy for entrepreneurship sustainability with a mean (M) value of 4.01 , innovativeness and taking a positive business risk by entrepreneurs help to sustain business has ( $M=3.66)$ as they agreed. The respondents also strongly disagreed $(M=1.16)$ with the statement that entrepreneurs perceive business negatively in Niger State due to the activities of the insurgency. The respondents also strongly agreed that 
Business Perception as a Strategy for Sustaining Entrepreneurship in the Face of Insurgency in Niger State, Nigeria.

entrepreneurship education helps in business sustainability (M4.37). Furthermore, the respondents equally disagreed on average that environmental knowledge does not affect business sustainability in Niger State $(M=2.00)$ and sustained business, straightens entrepreneurs in Niger State recorded (M3.51) as the respondents agreed.

On the effect of insurgency on business sustainability, the respondents agreed that amidst insurgency, entrepreneurship activities can be sustained with (M3.91), while they strongly agreed that insurgency activities have halted many businesses and other entrepreneurs quit Niger State with (M4.55). On the question that entrepreneurship sustainability doesn't depend on the level of peace and security of an area, the respondents strongly disagreed (M 1.39). Finally, on average, the respondents strongly agreed that insecurity limits the sources of funds available to entrepreneurs in Niger State with (M 4.11).

\section{Fitness of Model}

The study started analyzing to determine how fit the relationships between business perception and entrepreneurship sustainability are. Table 3 presents the regression model obtained from the analysis.

Table 3: Model Fitness

\begin{tabular}{|l|l|l|l|l|}
\hline & Pearson-R & R-square & Adjusted R-squared & SEE \\
\hline $\begin{array}{l}\text { Entrepreneurship } \\
\text { sustainability }\end{array}$ & 0.7985 & 0.6376 & 0.5129 & 1.6996 \\
\hline
\end{tabular}

Source: SPSS-26, 2021

As presented in Table 3, the R-square shows that business perception determines $63.76 \%$ of the variation in entrepreneurship sustainability. This shows that the model has a good fit and indicating that business perception has a huge impact on entrepreneurship sustainability.

\section{Analysis of Variance Result}

The Analysis of Variance (ANOVA) result is shown in Table 4. The finding further confirms that the regression model of business perception on entrepreneurship sustainability is significant for the data. This was captured by $F=19.833$ and $p$-values of 0.000 which is less than 0.05 .

Table 4- Result of ANOVA

\begin{tabular}{|l|l|l|l|l|l|l|}
\hline \multicolumn{7}{|l|}{ ANOVA } \\
\hline Model & & Sum of Squares & Df & Mean Square & F-statistic & Sig. \\
\hline 1 & Regression & 8.015 & 1 & 8.015 & 19.833 & $0.000^{\mathrm{b}}$ \\
\hline & Residual & 122.457 & 303 & 0.404 & & \\
\hline & Total & 130.472 & 304 & & & \\
\hline
\end{tabular}

Source: SPSS-25, 2021

\section{Statistical Test of Hypotheses}

The hypothesis was tested by using simple linear regression and determined using $p$-values of the t-statistics (or $t$-value). The null hypothesis is to be rejected if the $p$-value is less than 0.05 ; or otherwise accepted, if it is greater than 0.05.

Table 5: Regression Result

\begin{tabular}{|l|l|l|l|l|}
\hline & Coef. & Std. Err. & t-values & p-values \\
\hline Cons_ & 1.935 & 0.128 & 15.083 & 0.000 \\
\hline Business Perception & 0.236 & 0.053 & 4.453 & 0.000 \\
\hline
\end{tabular}

Source: SPSS-26, 2021

\section{Test of Hypothesis}

$\mathrm{H}_{0}$ : Business Perception has no significant effect on Entrepreneurship sustainability in Niger State

From the regression result in Table 5, the calculated t-value for the relationship between business perception and entrepreneurship sustainability is 4.453 and the $p$-value computed is 0.000 at 95 percent confidence levels. We dismiss the null hypothesis $\left(\mathrm{H}_{0}\right)$ since the $\mathrm{p}$-value is less than 0.05 (or $5 \%$ ) when the degree of significance is used and it thus showed that business perception has a significant effect on entrepreneurship sustainability in Niger state. 
Business Perception as a Strategy for Sustaining Entrepreneurship in the Face of Insurgency in Niger State, Nigeria.

\section{Discussion of findings}

Findings from the analysis showed that business perception has a positive and statistically significant effect on entrepreneurship sustainability in Niger State. This implies that despite the high insecurity challenges and insurgency operations in Niger State, entrepreneurs still perceive entrepreneurship and entrepreneurial activities positively believing that amidst all odds, there is light at the end of the business tunnel. This finding is consistent with the findings of Josiah (2017) who found business perception to be a key driver of business success. The study equally disagrees with the findings of Fatai and Farida (2016) who found an inverse relationship between business perception and SMEs growth.

\section{CONCLUSION AND RECOMMENDATIONS}

In conclusion, business perception and entrepreneurship sustainability in the face of insurgency in Niger State Nigeria were examined to access its efficacy as a strategy in sustaining entrepreneurship. The study hypothesized that business perception has no significant effect on entrepreneurship sustainability in Niger State. It was found that business perception has a positive and significant effect on entrepreneurship sustainability in Niger State and concludes that business perception is a strategy for sustainable entrepreneurship in Niger State.

The study recommended that there should be proper orientation and encouragement to Niger State entrepreneurs to maintain or even improve on their current entrepreneurial mindset, perceiving entrepreneurial opportunities amidst insecurity challenges.

\section{REFERENCES}

1) Abbah, I.(2020). Opportunity reorganization and business growth in Southeast Nigeria. Journal of Entrepreneurship Research. 8(1): 86-100.

2) Abdul, A. (2017). Insurgency and strategies for entrepreneurship survival. Journal of Strategic Studies. 2(2): 44-60.

3) Abdullasami,A.(2020).Effect of entrepreneurial and managerial competencies on the growth of women entrepreneurs. Journal of entrepreneurial Behavior \& Research, 6(3): 95-112.

4) Adaba, A.(2020). Managing constraints in entrepreneurial ventures. International Journal of Entrepreneurial Research. 7(5), 34-55.

5) Adabe, G.(2020). Psychological perspectives on entrepreneurship. Journal of Current Directions in Psychological Science. 6(1), 5-18.

6) Adamu. A.(2019). Entrepreneurial performance and model focusing. Journal of Business Management, 6(3): 55-65.

7) Adebayo, A.(2019). Differences between managers and entrepreneurs in a business environment. Journal of Entrepreneurship Research. 5(3):69- 73.

8) Ahmed, L(2019). Assessing the work environment for Innovativeness. Journal of Management Sciences, 3(9), 54-71.

9) Ajah, A. (2020). Self-efficacy toward a unifying theory of behavioral change. Psychological Review, 4(2), 91-105

10) Akpofi, H.M.(2019). Opportunity recognition as pattern recognition: How entrepreneurs connect the dots to identify new business opportunities. Academy of Management Perspectives, 2(1): 4-19.

11) Anda, A.(2017). ). The impact of environment and entrepreneurial perceptions on business-creativity. Journal of Entrepreneurship Research. 4(2):79- 93.

12) Anoke, A.F.(2019). Entrepreneurship education and profitability of entrepreneurs in Ebonyi State Nigeria. International Journal of Management Sciences, 4(3): 81-100.

13) Ayodeji, A.(2018). A competency-based perspective on entrepreneurship growth. Journal of Small Business Management, 11(2):52-69.

14) Benard, O.(2018). The big five and venture capital survival: Is there a linkage? Journal of Business Venturing, 9(4), 65-82

15) Eze, E.(2019). Influence of values, beliefs, attitudes, and leadership styles in the entrepreneurship growth. Journal of Entrepreneurship Development. 6(4):99-114.

16) Ezekiel, D.(2019). Assessing the work environment for creativity. Journal of Management Research, 9(4): 11-23.

17) Fatai, A.L., Rowland,E.W., \& Omisade,E.A.(2016). Critical success factors for sustainable entrepreneurship in SMEs: Nigeria perspective. Mediterranean Journal of social sciences, 7(3):338-346.

18) Fatai, M.C. \& Farida, L.(2016). Knowledge sharing and business perception on SMEs performance in Indonesia. International Journal of scientific \& technology Research. 5(11):209-211.

19) Gbande, C.(2018). Differences between entrepreneurs and managers in large organizations.

20) Idris, U.(2019). The role of mentorship on the perception of success for women entrepreneurs in Niger State. International Journal of Economics and Allied matters. 7(5):314-330. 
Business Perception as a Strategy for Sustaining Entrepreneurship in the Face of Insurgency in Niger State, Nigeria.

21) Inuwa, F.U., Muhammad, B.M.(2019). Impact of insurgency on the growth of small business in Maiduguri, Borno State, Nigeria. Duse Journal of Economics and Development Studies.7(1):95-102.

22) Jato, M.(2019). Ways to successful entrepreneurship: parenting, personality, entrepreneurial alertness, and interests. Journal of Organizational Behavior.5 (4): 98-118.

23) Joel, N. (2020).Insurgency and business survival in Nigeria. Journal of Forensic Studies, 2(1), 57-69

24) Josiah, P.P(2017). The influence of perception on entrepreneurial success. Unpublished PhD Theses. Retrieved from http:firescholars.seu. edu/honour/60. Journal of Business Venturing, 1(2): 10-25.

Journal of Business Venturing, 8(6):215-228.

25) Lukman, M.(2020) Inference of perception on entrepreneurial productivity. International Journal of Humanities. 5(4): 315-328.

26) Mbam, I.(2021). Effect of covid 19 and entrepreneurs business perception. Journal of Entrepreneurship and Development, 5(3): 75-88.

27) Mbeh,O.(2019). : Human and social capital in the entrepreneurial process. Journal of Socio-Economics, 2(1): 18-37.

28) Mishre, R.A.,\& Zachary, T.D.(2014) Environmental factors and entrepreneurs productivity. Journal of Entrepreneurship Development. 8(5): 301-314.

29) Nduka, O.(2020). Perception and SMEs survival in Nigeria. Journal of Small Business. 9(5):67-81

30) Ohida, M.(2018). Entrepreneurs' perceived chances for success. Journal of Business Venturing,4(1), 7-108.

31) Onu, A.N.(2018). Effect of microfinance services on the growth of women entrepreneurial business in South East Nigeria. Journal of Economics and Allied Studies, 7(5):79-94.

32) Osita. C.F.(2020) Apprenticeship and entrepreneurship growth in South-East Nigeria. Journal of Management Sciences. $7(3): 22-37$.

33) Tende, S.B.(2019). Entrepreneurial mindset and SMEs growth in Nasarawa State. Journal of Entrepreneurship and Research, 6(7): 121-133.

34) Tsebam, J.(2019). Executive personality, capability signs, and risk taking and business growth. Journal of Entrepreneurship. 5(4): 255-267.

35) Utara, S. (2019). Effects of acquired knowledge on entrepreneurial performance. Journal of Entrepreneurship Development and Research. 8(6):215-229.

36) Yahaya, U.(2019). Opportunity recognition and survival of entrepreneurs. Academy of Management Perspectives, 2(1): 10-19. 